\title{
Tohtoriksi naisena, äitinä ja vaimona
}

\author{
$\Psi$ \\ Ei ole lainkaan tavatonta, että työelämään kiinnittynyt uranainen pyrkii \\ yhdistämään työn, väitöskirjan teon sekä roolinsa äitinä ja vaimona. \\ Espoon työväenopiston rehtori Tarja Lang teki sen vuosina 2005-2011. \\ Hän haki aiheensa läheltä omaa ihoa ja tutki kansalaisopistojen \\ naisrehtoreita, kansansivistäjänaisia.
}

LANG PUHUU KANSANSIVISTYKSEN " näkymättömistä naisista”. Rehtori näkyy yhteisössään aina, mutta Langin mukaan naisrehtoreita myös vähätellään ja sivuutetaan. Omasta kokemuksestaan hän tietää myös sen, että tällaisen johtavassa asemassa olevan virkamiehen on hyvä olla myös poliittisesti sitoutunut, sillä se mahdollistaa pääsyn kunnallispolitiikassa niihin piireihin, joissa asioita puhutaan, tehdään linjauksia ja päätöksiä. Sitoutumaton jää helpommin sivuun.

Väitöskirjaansa "Myyttisestä sankarirehtorista opistoäidiksi ja manageriksi - Sukupuolen näkökulma kansalais- ja työväenopiston johtajuuteen” Tarja Lang luonnehtii feministisen uransa jatkoksi, haluksi kehittää itseä.

- En voisi tehdä tätä työtä suuren opiston rehtorina, jos en tunne vapaan sivistystyön ja naisrehtoriuden taustoja, historiaa, lähtökohtia ja sukupuolisia merkityksiä. Vapaa sivistystyö on ollut naisille oivallinen väylä kehittää itseään myös naisina, hän perustelee.

Ajatuksen väitöskirjan teosta Tarja Lang sai jatkoopintojen loppuvaiheessa, vaikka kiinnostus tutkimukseen virisi jo pro gradun aikoihin vuonna 1995. Kuitenkin vasta, kun Espoon työväenopistossa oli vuonna 2004 saatu päätökseen organisatorinen uudistus, aikomukseen saattoi tarttua.

Kun tutkimustyö on nyt vuosien ponnistelujen jälkeen ohi, hän myöntää, ettei olisi jaksanut rehtorin työtä ilman tutkimuksen tuomaa toista todellisuutta. Opiston organisaatiouudistus oli johtanut työuupumukseen ja terveyden vakavaan oireiluun.

- Sisu paukahti päälle. En halunnut luovuttaa, vaan aloin purkaa asioita tutkimussuunnitelmaksi. Halusin paikantaa itseni kansansivistyksen pitkässä historiassa. Suomalainen kansansivistäjänainen on raivannut aina paikkansa kovalla työllä ja pyrkinyt tehtävien hoitamiseen uupumattomasti. Näen suomalaiset naisrehtorit talonpoikaisnaisten perillisinä, samanlaisen työkulttuurin jatkajina. Kaikkiin töihin rohjetaan tarttua.

\section{FLOWN IMUSSA}

Tarja Lang kokee tutkimuksen teossa palkitsevimpana mukaan tempautumisen. Sitä kutsutaan myös flow' ksi. Flown saa aikaan tiedonjano, loputon kiinnostus, jossa uusi havainto tai löydös kannattelee eteenpäin kohti kiinnostusta tietää lisää. Prosessi on luova. Flow oli päallä muiden muassa niinä lukuisina varhaisina lauan- 
taiaamuina, jolloin hän muun perheen nukkuessa hakeutui työhuoneeseensa ja uppoutui työhönsä.

- Tutkimuksenteon imu muutti ajattelua ja lähestymiskulmaa kaikkeen työhön ja elämään. Sain hyvän ohjauksen, eikä tutkimusryhmän kannustavaa merkitystä voi yliarvioida, kuvailee Tarja Lang, joka koki vuosien aikana tutkimusryhmänsä liki toisena perheenään. Ryhmän jäseniltä sai kannustuksen ja rohkaisun lisäksi hyviä neuvoja ja tärkeää tietoa aikatauluista ja työn jäsentämisestä.

Tutkimusryhmän ulkopuolelta kannustusta tuli vähemmän.

- Sain päin naamaakin kommentteja, niin naisilta kuin miehiltä, että ”onpas tyhmä tutkimuskohde”.

Keskeistä oli kuitenkin perheen tuki. Tarja Langin aviomies on tutkija ja ymmärsi, mitä väitöskirjan tekeminen merkitsee. Perheelle, aviomiehelle ja murrosikäiselle tyttärelle, vuodet olivat rankkoja, vaikka se ymmärsikin sen, että äiti sulkeutuu muilta työhuoneeseensa ja ilmestyy vasta illallispöytään. Ruokapöydässä ja saunassa puhe kiertyi useimmiten väitöskirjan asioihin, johonkin taustakirjallisuudesta juuri löydettyyn.

- Arjen pyöritys ei onnistu, jos puoliso ei ole itsenäinen. Kodin siivoamisen ostimme kyllä ulkopuolelta, sillä tutkimustyötä ei saa koskaan valmiiksi, jos on kaikkeen sopeutuva, kiltti perheenäiti. Alitajunta työskentelee tehokkaimmin taukojen aikana ja siksi tein koiran kanssa ulkoilulenkkejä. Muutuin epäsosiaaliseksi, koska aikaa ystäville ei ole. On myös vuosiksi kieltäydyttävä harrastuksista, kulttuurista ja viihteestä. Parilta vuodelta kesälomatkin jäivät pitämättä.

Moni väittelijä ihmettelee väitöstilaisuudesta selvittyään, miksi puhelin ei soi. Se ei ole soinut vuosiin, koska ystäville ja tutuille ei ole ollut aikaa. Langin ystäviä olivat vuosia aulis alasia, raili kilviä ja urpo harvoja. Hän seurusteli päänsä sisällä tutkimiensa naisrehtoreiden, ellien ja almojen, kanssa.

\section{TAKAPAKKIA JA ETENEMISTÄ}

Väitöskirjan teko työn ohessa, vaikka virkavapaita välillä ottaenkin, on etenemistä ja takapakkia. Vuoropuhelu tiedeyhteisön kanssa oli Langin kokemuksissa sahaavaa ja välillä perin turhauttavaa. Kun on kirjoittanut jo paljon pohjatekstiä ja se ei kelpaa, moni saattaa jättää siinä vaiheessa sikseen.
- Jokainen takapakki on tyrmäävä. Syntyy pelko, ettei koko tutkimus loppujen lopuksi menekään läpi. Hain siksi mahdollisimman kriittisiä esilukijoita. Koin, että väitöskirjan teon järjestelmä ei tue työssä olevaa tutkijaa, vaan se on tarkoitettu päätoimisille tutkijoille. Mutta oli vain haavojen nuolemisen jälkeen sisuunnuttava. Oli löydettävä omat vahvuudet ja keskeinen niistä on argumentaatiotaito.

Tutkijan on myös itse oltava itsenäinen ja aktiivinen. Kukaan ei tee puolestasi tai ota vastuuta. Vapaus velvoittaa. Työ- ja perheasiat on tehtävä selväksi ja mukavuudenhalusta on luovuttava.

- Askeettisuus ei kuitenkaan saa olla sataprosenttista. Kulmat kurtussa puskemisesta ei hyvää seuraa. Siksi hyvä viini, hyvä ruoka ja hyvä seura ovat antoisia välietappeja, joista taas lähtee energisenä ja kurinalaisesti jatkamaan töitä.

\section{SUKUPUOLENSA KIELTÄJÄT}

Osa Langin tutkimusaineistosta koostui nykypäivän kansanopistojen naisrehtoreiden haasteluista. Lang koki, että naisjohtajat haluavat muokkautua miesmäisiksi tai ainakin sukupuolineutraaleiksi, jotta he olisivat uskottavia tehtävässään, pukeutumista myöten. Moni naisrehtori vakuuttikin sukupuolineutraaliutta tavoitellessaan, ettei sukupuolella ole väliä.

- Yhdestä tutkimuksesta poikii aina ajatuksia uusiksi. Olisi hyvä tutkia työyhteisöjen "hankalia naisia". Olen persoonana vahva ja näkyvä, siksi käsitykseni mukaan "hankalan akan" maineessa. Puhun paljon, nostan naisten asemaa esille, kun eri nostattaviin tilaisuuksiin halutaan vain miehiä puhujiksi, kuvailee sukupuolestaan rehtorina tietoinen Tarja Lang.

Lang uskoo oman tutkimuksensa merkitykseen ja hyötyyn kansalaisopistokentässä.

- Tutkimus on meille kaikille yhteinen. Haluan jakaa sen kaikkien kanssa, jotka haluavat nyt ja tulevaisuudessa kehittää vapaata sivistystyötä ja hakea sille suuntaa, hän sanoo.

Pakko jäädä miettimään, olisiko myös tuo "jakaa kaikkien kanssa" ja "meidän tutkimus" ainakin osin sukupuolisidonnainen ajattelutapa.

Tarja Lang väitteli 22.1.2011 Helsingin yliopistossa. 